\title{
Nitrogen sources and Bioaab inclined yield and nutrients uptake specifically in Triticum aestivum
}

\author{
Imran Azeem ${ }^{1,2}$, Adnan Anwar Khan ${ }^{1,3}$, Hamida Bibi ${ }^{1}$, Kamran Azeem ${ }^{4}$, \\ Farah Naz ${ }^{5}$, Ibadullah ${ }^{1}$, Kashif Khan ${ }^{6}$, Syed Aizaz Ali Shah ${ }^{7}$ and \\ Kamran Shah $^{8,9^{*}}$ \\ 1. Department of Soil and Environmental Sciences, The University of Agriculture, Peshawar 25120-Pakistan \\ 2. College of Resources and Environmental Sciences, China Agricultural University, Beijing-China \\ 3. College of Natural Resources and Environment, Northwest Agriculture and Forestry University, Yangling \\ 712100-China \\ 4. Department of Agronomy, University of Haripur-Pakistan \\ 5. Department of Soil and Water Conservation, Haripur-Pakistan \\ 6. College of Water and Soil Conservation, Northwest Forestry University, Harbin-China \\ 7. College of Horticulture, China Agricultural University, Beijing-China \\ 8. Department of Horticulture, The University of Agriculture, Peshawar 25120-Pakistan \\ 9. College of Horticulture, Northwest Agriculture and Forestry University, Yangling 712100-China \\ *Corresponding author's email: kamranshah801@nwafu.edu.cn ; kamranshah801@gmail.com
}

Citation

Imran Azeem, Adnan Anwar Khan, Hamida Bibi, Kamran Azeem, Farah Naz, Ibadullah, Kashif Khan, Syed Aizaz Ali Shah and Kamran Shah. Nitrogen sources and Bioaab inclined yield and nutrients uptake specifically in Triticum aestivum. Pure and Applied Biology. Vol. 8, Issue 4, pp2311-2325. http://dx.doi.org/10.19045/bspab.2019.80178

\begin{tabular}{llll}
\hline \hline Received: 29/04/2019 & Revised: 29/06/2019 & Accepted: 25/07/2019 & Online First: 09/08/2019 \\
\hline \hline
\end{tabular}

\section{Abstract}

Low dose of nitrogen application leads to less growth and yield, high dose leads to crop burn, organic and inorganic fertilization is another major concern for recent growers and consumers. To understand this phenomenon current experiment consisted of thirteen treatments of organic (FYM) and inorganic (urea) ratios $(0: 100,20: 80,40: 60,60: 40,80: 20$ and 100:0) with and without Bioaab and control was conducted at New Developmental Research Farm, The University of Agriculture, Peshawar. Two factorial, Randomized complete block (RCBD) was used with plan mean comparison having three replications. Basal dose of $\mathrm{P}$ and K were applied @ $90 \mathrm{~kg} \mathrm{ha}^{-1}$ and $60 \mathrm{~kg} \mathrm{ha}^{-1}$ respectively at the time of sowing. Application of Bioaab significantly enhanced grain yield $\left(3247 \mathrm{~kg} \mathrm{ha}^{-1}\right)$, total dry matter $\left(8993 \mathrm{~kg} \mathrm{ha}^{-1}\right)$, plant height $(92.1 \mathrm{~cm})$, spike length $(10.1 \mathrm{~cm})$, grain spike ${ }^{-1}(52)$, thousand grain weight $(46.2 \mathrm{~g})$, soil electrical conductivity $(0.29$ $\left.\mathrm{dSm}^{-1}\right)$, soil organic matter $(1.34 \%)$, soil nitrogen $\left(2669 \mathrm{mg} \mathrm{kg}^{-1}\right)$, plant nitrogen $\left(1.56 \mathrm{mg} \mathrm{kg}^{-1}\right)$ and uptake of nitrogen $\left(143.47 \mathrm{~kg} \mathrm{ha}^{-1}\right)$. Application of organic and inorganic ratio 60:40 significantly increased grain yield $\left(3695.8 \mathrm{~kg} \mathrm{ha}^{-1}\right)$, total dry matter $\left(9806.3 \mathrm{~kg} \mathrm{ha}^{-1}\right)$, plant height $(97.9 \mathrm{~cm})$, spike length $(10.5 \mathrm{~cm})$, grain spike ${ }^{-1}(59.2)$, thousand grain weight (48.3 g), soil nitrogen $\left(2791 \mathrm{mg} \mathrm{kg}^{-1}\right)$, plant nitrogen $(1.78 \%)$, uptake of nitrogen $\left(174.86 \mathrm{~kg} \mathrm{ha}^{-1}\right)$. However, soil organic matter $(1.45 \%)$ and electrical conductivity $(0.30$ $\mathrm{dS} \mathrm{\textrm {m } ^ { - 1 }}$ ) were observed with application of $\mathrm{N}$ from sole organic source. Results indicates that application of Bioaab with 60:40 organic and inorganic ratios increase yield, nutrients uptake and ultimately production in wheat.

Keywords: Bioaab; Inorganic; Nitrogen; Organic; Wheat 


\section{Introduction}

Wheat (Triticum aestivum L.) ranks first in world cereals crops, belongs to family Poaceae. It is grown as a rabbi and winter crop in Pakistan. It is a major, stable food crop and highly nutritious diets for human beings. Its straw is used in livestock industry as feed whereas it grains was used as a raw material for making bread, pastry and biscuit. It is grown all over the world as moderate as rainfed as well as irrigated areas. The whole wheat grains have carbohydrates (69\%), crude protein (12\%), fats $(2 \%)$, ash (2\%) and crude fiber $(3 \%)$ [1]. The population of Pakistan directly or indirectly depends on wheat husbandry. The requirements of wheat in Pakistan are growing at very high rate.

During 2010-2011, total world production of wheat was 651 million tons, which is third most producing after rice and maize. During 2011 the cultivation of wheat in Pakistan was 8649.79 thousand hectares, and its production was 23473.42 thousand tones. Average yield of wheat was $2714 \mathrm{~kg} \mathrm{ha}^{-1}$. Total cultivated area of Khyber Pakhtunkhwa at the same year was 729.31 thousand ha and its production was 842.69 thousand tones. Average yield was $1550 \mathrm{~kg} \mathrm{ha}^{-1}$. [2].

Nitrogen (N) is basic nutrient for plant growth and important part of plant tissue [3] and it play an important role in the production of chlorophyll, protein, which ultimately enhance plant growth, yield and reproduction [4]. Plant takes $\mathrm{N}$ in the form of ammonium nitrate, which is further used for growth and production process.

The organic material enhances total porosity i.e macro and micro pores, bulk density, soil water penetration, nutrient holding capacity and soil hydraulic conductivity as compared to untreated soil [5]. The application of manure plays vital role in rising fertility of soil, manures are massive material made of animals and plant wastes. Plant takes nutrient from these natural sources [6]. Management of both organic and in organic $\mathrm{N}$ improved agricultural production in arid and semi-arid areas [7]. Organic carbon also increases with increasing of organic manure and compost than the application of synthetic fertilizer. The application of manure increases the soil fertility and improved wheat productivity [8]. An effective microorganism (EM) or beneficial microorganism technology consists of a mixed culture of a beneficial microorganism and a naturally occurring microorganism [9]. The main microorganisms cultured in EM are photosynthetic bacteria (Rhodopseudomonas plastris and Rhodobacter sphacrodes), Lactobacillus (Lactobacillus plantarum, Lactobacillus casei and Streptococcus lactis), Yeast (Saccharomyces) and and actinomycetes (Strptomyces spp.). It promotes photosynthesis, produces bioactive substances such as hormones and enzymes, prevents soil diseases, promotes the degradation of lignin in the soil, and increases crop growth and yield [10, 11]. In Pakistan, this technology was introduced in 1990 by the Nature Farming Research Centre, University of Agriculture, Faisalabad. As probiotics in poultry and livestock waste, various experiments have been conducted to enhance the composting and recycling process to reveal the benefits of this technology in crop production [12]. Studies show that inoculating BM cultures into soil and plant ecosystems can improve soil quality, soil health, plant growth, yield, and crop quality [13].Current experiment was conducted to determine the optimum treatment of organic and inorganic fertilizers with and without Bioaab on wheat plant.

\section{Materials and methods Site description}

The experimental site is located at $34.0167^{\circ}$ $\mathrm{N}$ latitude and $71.5833^{\circ} \mathrm{E}$ longitude at an altitude of 350-m-above sea level. Climate of the area is semiarid where average annual rainfall is very low (300 to $500 \mathrm{~mm}$ ), 60-70 $\%$ rainfall occurs in summer, while the 
remaining $30-40 \%$ rainfall occurs in winter and maximum wind speed is $35 \mathrm{~km} / \mathrm{h}$ [14, 15]. The soil at the locality contains $32.80 \%$ Clay, $53.20 \%$ Silt, $14 \%$ Sand, however the textural class fall in Silty clay loam [39]. The experiment was conducted at New Developmental Research Farm of the University of Agriculture, Peshawar during 2015-2016.

\section{Experimental design}

The experiment consist of 2 factor i.e. sources of organic $\mathrm{N}$ and ratio with inorganic fertilizer. These treatments were arranged according to two Factorial Randomized Completer Block Design (RCBD) with three replications. The treatment plot size was $4 \mathrm{x}$ $1.8 \mathrm{~m}^{2}$ having rows with row to row distance of $30 \mathrm{~cm}$ and row length of four meter. Basal dose of P and K were applied @ 90 and 60 kg $\mathrm{ha}^{-1}$, respectively at the time of sowing. The recommended $\mathrm{N}$ levels were met either from organic sources (FYM) or from inorganic fertilizer of urea or both sources were combined in different ratios with the interaction of Bioaab. The treatment details are given below in (Table 1).

Table 1. Treatment combination of Bioaab and $N$ integration

\begin{tabular}{|c|c|c|c|}
\hline \multirow{2}{*}{ Treatments } & \multirow{2}{*}{ Bioaab } & \multicolumn{2}{|c|}{ Percent share of N from the source } \\
\cline { 2 - 4 } & & Organic & Urea \\
\hline T1 & Control & 0 & 0 \\
\hline T2 & With & 100 & 0 \\
\hline T3 & With & 80 & 20 \\
\hline T4 & With & 60 & 40 \\
\hline T5 & With & 40 & 60 \\
\hline T6 & With & 20 & 80 \\
\hline T7 & With & 0 & 100 \\
\hline T8 & Without & 100 & 0 \\
\hline T9 & Without & 80 & 20 \\
\hline T10 & Without & 60 & 40 \\
\hline T11 & Without & 40 & 60 \\
\hline T12 & Without & 20 & 100 \\
\hline T13 & Without & 0 & \\
\hline
\end{tabular}

Data in (Table 2) showed that the soil under study was calcareous in nature, alkaline in reaction. Silt loam in texture, low in organic contents, poor in available total nitrogen (TN), phosphorus and potassium contents.

\section{Preparation of Bioaab}

Bioaab solution was prepared by following the standard procedure. One liter of Bioaab was taken in a close container. Then $20 \mathrm{~L}$ of water was added with one $\mathrm{kg}$ of sugar and placed for 7 days in sunlight. The prepared Bioaab was then applied to the treatments accordingly (15ml/ plot).

\section{Morphological analysis}

Plant height was determined by random selection of 5 plants in each treatment, measured through meter rod from base to top of the plant. Spike length was determined by random selection of 5 spikes in each experimental unit, measured through meter rod from the tip of uppermost spikelet to the base of the rachis. Randomly selected five spikes from each experimental unit were thrashed separately and counted the numbers of grain per spike. Randomly selected thousand normal sized grains from each plot 
and weighed with the help of electric balance. For total dry matter, four central rows were harvested in each $8 \mathrm{~m}^{2}$ plot. The harvested rows of wheat crop were sun dried for seven days. After one week the harvested crop was weighed with the help of electric balance and total dry matter was converted to $\left(\mathrm{kg} \mathrm{ha}^{-1}\right)$ by using formula:

$$
\text { Total dry matter }=\frac{\text { Total dry matter of four rows } \times 1000}{\text { No. of rows harvested } \times \text { row to row distance } \times \text { row length }}
$$

The harvested four rows of total dry matter of wheat of each $8 \mathrm{~m}^{2}$ plot were thrashed by micro-plat thresher. The grains were cleaned properly and were weighted with help of top loader balance. Harvested index was calculated by using the following formula:

$$
\text { Harvested index }(\mathrm{HI})=\frac{\text { Grain yield }}{\text { Biological yield }} \times 100
$$

Table 2. Physio-chemical properties of composite sample

\begin{tabular}{|c|c|}
\hline Property & Concentration \\
\hline Silt & $66.2 \%$ \\
\hline Sand & $28.8 \%$ \\
\hline Clay & $5.6 \%$ \\
\hline Textural class & Silt loam \\
\hline $\mathrm{pH}$ & 7.83 \\
\hline EC(e) & $0.27 \mathrm{dSm}^{-1}$ \\
\hline Lime & $18.3 \%$ \\
\hline Organic matter & $0.87 \%$ \\
\hline N contents (Total) & $0.16 \%$ \\
\hline $\mathrm{P}($ AB-DTPA extractable $)$ & $3.18 \mathrm{mg} \mathrm{kg}^{-1}$ \\
\hline $\mathrm{K}$ (AB-DTPA extractable $)$ & $62.1 \mathrm{mg} \mathrm{kg}^{-1}$ \\
\hline
\end{tabular}

\section{Soil analysis}

The soil sample collected from either field at $(0-20 \mathrm{~cm})$ depth after termination of experiments or during pre-sowing stage was air dried under shad followed by sieving through $2 \mathrm{~mm}$ sieve. These samples were then stored in properly labeled plastic bags for succeeding various analyses. The $\mathrm{pH}$ meter was used to measure $\mathrm{pH}$ of the soil samples, $\mathrm{pH}$ was determined by 1:5 soil: water [16], electric conductivity (ECe) [17], Organic matter was determined by the method given by Walkley and Black [18]. In plant and composite soil sample TN was determined by Kjeldhal digestion method.

\section{Statistical analysis}

The data noted was subjected to Analysis of Variance (ANOVA) technique appropriate for RCBD split plot design with two factor experiment. In case results were found significant means were compared by using Least Significant Difference (LSD) test at 5\% level of significance. Statistical software Statistix (8.1) was used for calculating ANOVA and LSD value $[14,15]$.

\section{Results and discussion}

Grain yield, biological yield and harvest index

Grain yield and biological yield were significantly influenced by bioaab (B), organic and inorganic ratios (R), control vs rest and interaction between $\mathrm{B} \times \mathrm{R}$. however, harvest index were non-significant with application of bioaab and control vs rest (Table 3). Bioaab application resulted higher grain yield (3248 $\mathrm{kg} \mathrm{ha}^{-1}$ ), biological yield (8994 $\mathrm{kg} \mathrm{ha}^{-1}$ ) as compared without bioaab. Effective microbes (EM) increased 
decomposition rate of organic materials which fulfill requirement of crop and enhanced productivity [19]. [20] (2015) study showed that grain yield and biological yield increased by $8 \%$ with the application EM as compare without EM.

60:40 ratio of organic and inorganic resulted higher grain yield (3696 $\left.\mathrm{kg} \mathrm{ha}^{-1}\right)$ and biological yield (9806 $\mathrm{kg} \mathrm{ha}^{-1}$ ). However, harvest index was (35.9\%) with 40:60 ratio. Whereas, control plots produced less yield as compared to rest treated plots. [21] (2010) reported that half organic and half inorganic fertilizer increased the production of total dry matter and grain yield. [22] (2012) reported that $50 \%$ of $\mathrm{N}$ and $50 \%$ of FYM or $50 \%$ of PM significantly enhanced biological yield, grain yield and harvest index.

Interaction of ratios and Bioaab showed that grain yield, biological yield and harvest index were significantly increased from 0:100 organic and inorganic $\mathrm{N}$ ratios up to $60: 40$ with further increased in organic ratios grain yield, biological yield and harvest index was declined with the application of Bioaab and without whereas, without bioaab was slightly decreased as compared with bioaab (Fig. 1, 2 \& 3).

Plant height, spike length, grain spike ${ }^{-1}$ and thousand grains weight

Plant height, spike length, grains per spike and thousand grain weight were significantly influenced by bioaab (B), organic and inorganic ratios $(\mathrm{R})$, control vs rest and interaction between $\mathrm{B} \times \mathrm{R}$ while interaction between $\mathrm{B} \times \mathrm{R}$ plant height and thousand grain weight was non-significant (Table 4). Bioaab application resulted highest plant height $(92.1 \mathrm{~cm})$, spike length $(10 \mathrm{~cm})$, grains per spike (52) and thousand grain weight (46.1 g) as compared without bioaab. [23] (2008) reported that the application of bio fertilizer with integrated $\mathrm{N}$ improved plant height, grain per spike and thousand grain weight. Application of bio fertilizer with integrated $\mathrm{N}$ management enhanced spike length, and grain spike ${ }^{-1}$ [24].

Application of 60:40 ratio of organic and inorganic resulted height plant height (97.9 $\mathrm{cm})$, spike length $(10.6 \mathrm{~cm})$, grains per spike (59.3) and thousand grain weight (48.3 g). Whereas, control plots produced less as compared to rest treated plots. Synthetic fertilizer $\mathrm{N}$ only or mixed with organic $\mathrm{N}$ significantly increased plant height and grain per spike of wheat [25]. [26] (2006) observed that application of integrated $\mathrm{N}$ management significantly increased spike length and number of grain per spike. [22] (2012) reported that application of $50 \%$ organic and $50 \%$ inorganic $\mathrm{N}$ significantly enhanced spike length and thousand grain weight.

Interaction of ratios and Bioaab showed that spike length and grain per spike were significantly increased from 0:100 organic and inorganic $\mathrm{N}$ ratios up to 60:40 with further increased in organic ratios spike length and grain per spike was declined with the application of Bioaab and without whereas, without bioaab was slightly decreased as compared with bioaab (Fig. 4 \& $5)$.

Soil pH, Electric conductivity and Soil organic matter

$\mathrm{pH}, \mathrm{EC}(\mathrm{e})$ and soil organic matter (SOM) were significantly influenced by bioaab (B), organic and inorganic ratios (R), control vs rest and interaction between $\mathrm{B} \times \mathrm{R}$. while interaction between $\mathrm{B} \times \mathrm{R}$ EC(e) was nonsignificant (Table 5). Bioaab application resulted low $\mathrm{pH}$ (7.83 1:5), high EC(e) (0.266 $\mathrm{dsm}^{-1}$ ) and SOM (1.27 \%) as compared without bioaab. [23] (2014) reported that application of $\mathrm{BM}$ reduced soil $\mathrm{pH}$ and $\mathrm{EC}(\mathrm{e})$ as compared with inorganic $\mathrm{N}$ fertilizer. [27] (2005) reported that bio-fertilizer enhanced organic matter in soil.

Application of $100 \%$ organic fertilizer resulted low pH (7.810), high EC(e) (0.299 $\mathrm{dSm}^{-1}$ ) and high SOM (1.45 \%). Whereas, control plots were high $\mathrm{pH}$ as compared to 
rest treated plots, EC(e) and SOM were less found in control plot as compared to rest treated plots. [28] (2017) recorded highest soil organic matter in treatment plots with the application of mineral fertilizers with compost. Application of organic and inorganic $\mathrm{N}$ fertilizer significantly reduced soil $\mathrm{pH}$ with mineralization process and production of different acids such as amino acid, humic acid, glycin and cystein [29]. Addition of organic fertilizer reduced soil $\mathrm{pH}$ and increased SOM [30]. Application of integrated $\mathrm{N}$ management was significantly increased EC [31].

Interaction between Bioaab and organic and inorganic ratios was declined $\mathrm{pH}$ from 0:100 to $80: 20$ in both Bioaab and without Bioaab while with Bioaab remain constant for further increase in organic and inorganic ratios. soil organic matter was increased with increasing organic and inorganic proportion with and without Bioaab (Fig. $6 \& 7$ ).

\section{Soil total nitrogen, plant nitrogen concentration and nitrogen uptake}

Soil total nitrogen $(\mathrm{N})$, concentration of nitrogen and nitrogen plant uptake were significantly influenced by bioaab (B), organic and inorganic ratios $(\mathrm{R})$, control vs rest and interaction between $B \times R$. while interaction between $\mathrm{B} \times \mathrm{R}$ soil total nitrogen was non-significant (Table 6). Bioaab application resulted high soil total nitrogen contents (2669 $\left.\mathrm{mg} \quad \mathrm{kg}^{-1}\right)$, nitrogen concentration in plant $(1.6 \%)$ and uptake of nitrogen in wheat plant $\left(143.5 \mathrm{~kg} \mathrm{ha}^{-1}\right)$ as compared without bioaab. [32] (2002) stated that the addition of FYM with EM increased soil nitrogen $22.4 \%$. Similarly, [33] (2007) reported that slow decomposition of organic sources with EM slowly released nutrient leads more soil nitrogen. [34] (2010) reported that EM increased decomposition of organic fertilizer and mineralization process which leads to more N available to crop. [35] (2003) noted that uptake of nitrogen related with microorganisms that inhabit rhizosphere and play a very important role in $\mathrm{N}$ uptake by crop.

Application 60:40 ratio of organic and inorganic resulted higher soil total nitrogen (2791.7 $\mathrm{mg} \mathrm{kg}^{-1}$ ), concentration of nitrogen in plant $(1.78 \%)$ and uptake of nitrogen in plant (174.86 kg ha-1). Whereas, control plots were less as compared to rest treated plots. $[36,38](2006)$ who concluded that nitrogen content is significantly increased with organic sources but declined without organic sources. Addition of organic fertilizer enhance $\mathrm{N}$ content in plant [37]. Application of organic and inorganic fertilizer improved concentration of $\mathrm{N}$ and yield growth [36]. [28] (2017) find out that application of synthetic fertilizer with organic fertilizers to soil increased uptake of nitrogen.

Interaction of ratios and Bioaab showed that concentration and uptake of nitrogen in plant were significantly increased from 0:100 organic and inorganic $\mathrm{N}$ ratios up to $60: 40$ with further increased in organic ratios both were declined with the application of Bioaab and without whereas, without bioaab was slightly decreased as compared with bioaab (Fig. 8 \& 9). 
Table 3. Grain yield, biological yield and harvest index of wheat as affected by integrated nitrogen management with bioaab

\begin{tabular}{|c|c|c|c|}
\hline Treatments & $\begin{array}{c}\text { Grain yield } \\
\left(\mathrm{Kg} \mathrm{ha}^{-1}\right)\end{array}$ & $\begin{array}{c}\text { Biological yield } \\
\left(\mathrm{Kg} \mathrm{ha}^{-1}\right)\end{array}$ & $\begin{array}{c}\text { Harvest index } \\
(\%)\end{array}$ \\
\hline \multicolumn{4}{|l|}{$\mathrm{BM}$} \\
\hline With BM & $3248 \mathrm{a}$ & $8994 \mathrm{a}$ & 33.1 \\
\hline Without BM & $3013 \mathrm{~b}$ & $8476 \mathrm{~b}$ & 33.2 \\
\hline prob. & 0.034 & 0.042 & 0.948 \\
\hline \multicolumn{4}{|l|}{ Ratios } \\
\hline 0:100 & $2699 \mathrm{e}$ & $7822 \mathrm{e}$ & $32.1 \mathrm{c}$ \\
\hline $20: 80$ & $3206 \mathrm{c}$ & $8569 \mathrm{c}$ & $33.5 \mathrm{bc}$ \\
\hline $40: 60$ & $3459 \mathrm{~b}$ & $9128 \mathrm{~b}$ & $35.9 \mathrm{a}$ \\
\hline $60: 40$ & $3696 \mathrm{a}$ & $9806 \mathrm{a}$ & $34.7 \mathrm{ab}$ \\
\hline $80: 20$ & $2947 d$ & $8893 \mathrm{bc}$ & $32.3 \mathrm{c}$ \\
\hline 100:0 & $2775 \mathrm{e}$ & $8191 \mathrm{~d}$ & $30.4 \mathrm{~d}$ \\
\hline $\operatorname{LSD}_{(0.05)}$ & 152.209 & 351.947 & 1.636 \\
\hline \multicolumn{4}{|c|}{ Planned mean comparison } \\
\hline Control & $2144 *$ & $7142 *$ & $30.6 *$ \\
\hline fertilized plots & 3130 & 8735 & 33.1 \\
\hline prob. & 0.000 & 0.001 & 0.220 \\
\hline \multicolumn{2}{|c|}{ Interaction } & & \\
\hline $\mathrm{BM} \times \mathrm{R}$ & 0.049 & 0.047 & 0.015 \\
\hline
\end{tabular}

*Mean with different letter(s) in columns is significantly different at $\mathrm{p} \leq 0.05$

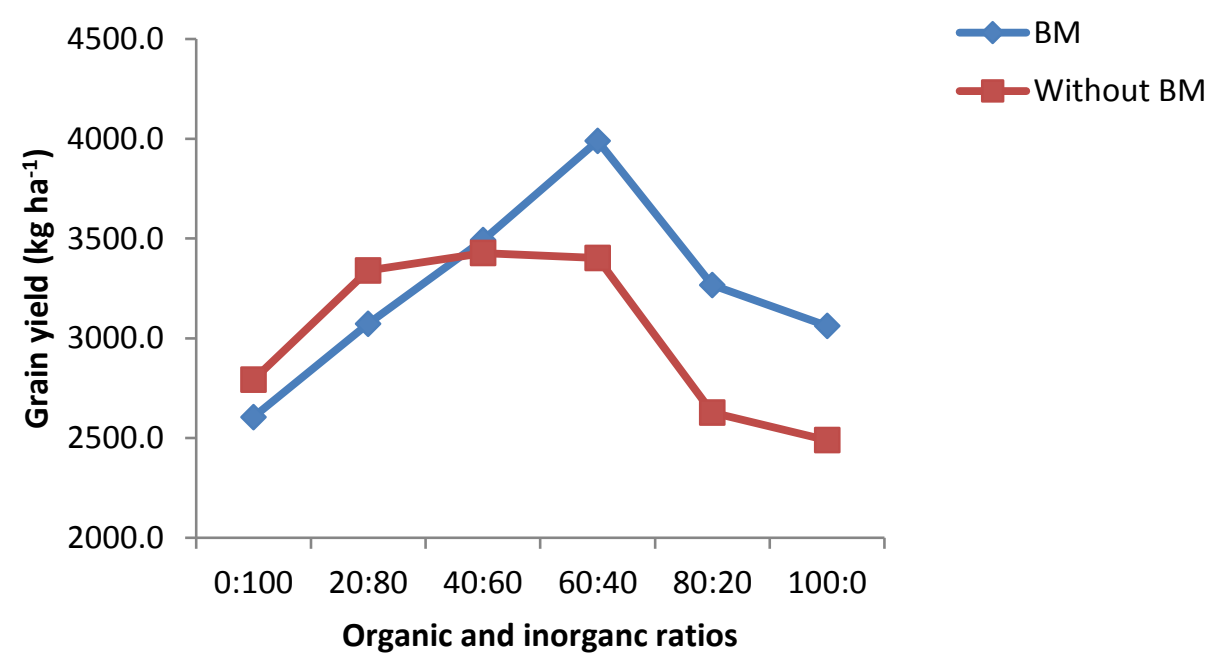

Figure 1. Grain yield as affected by bioaab with organic and inorganic ratios interaction 


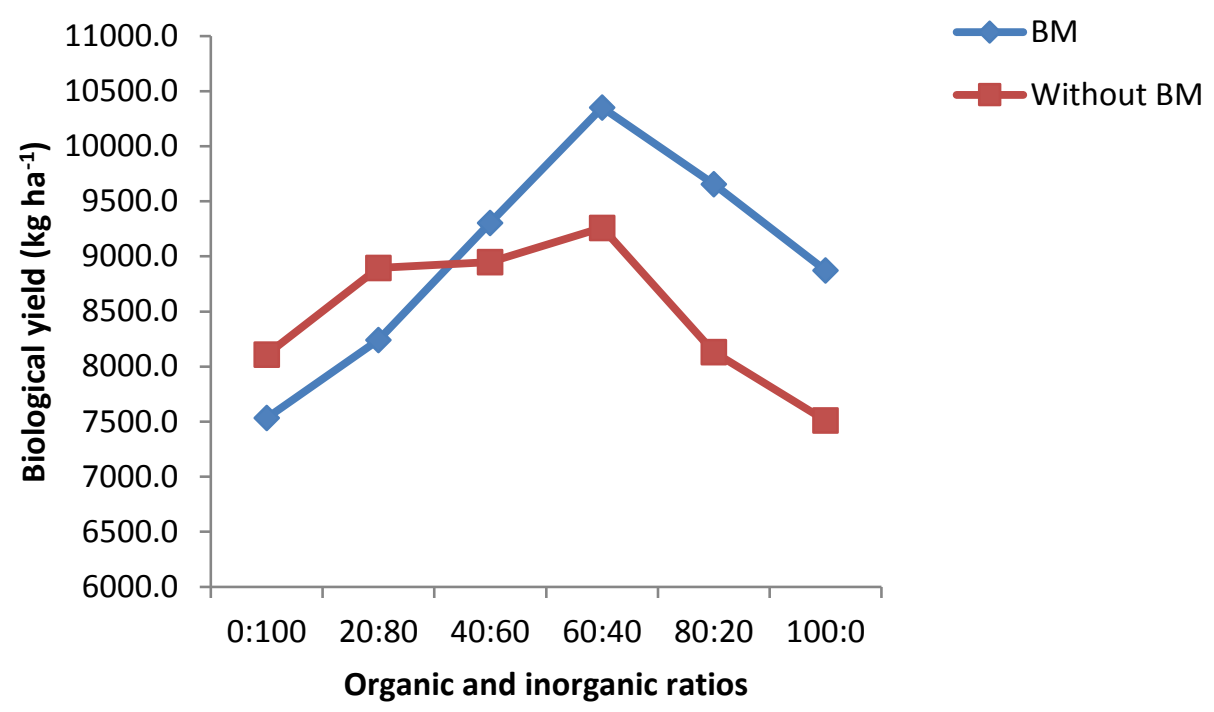

Figure 2. Biological yield as affected by bioaab with organic and inorganic ratios interaction

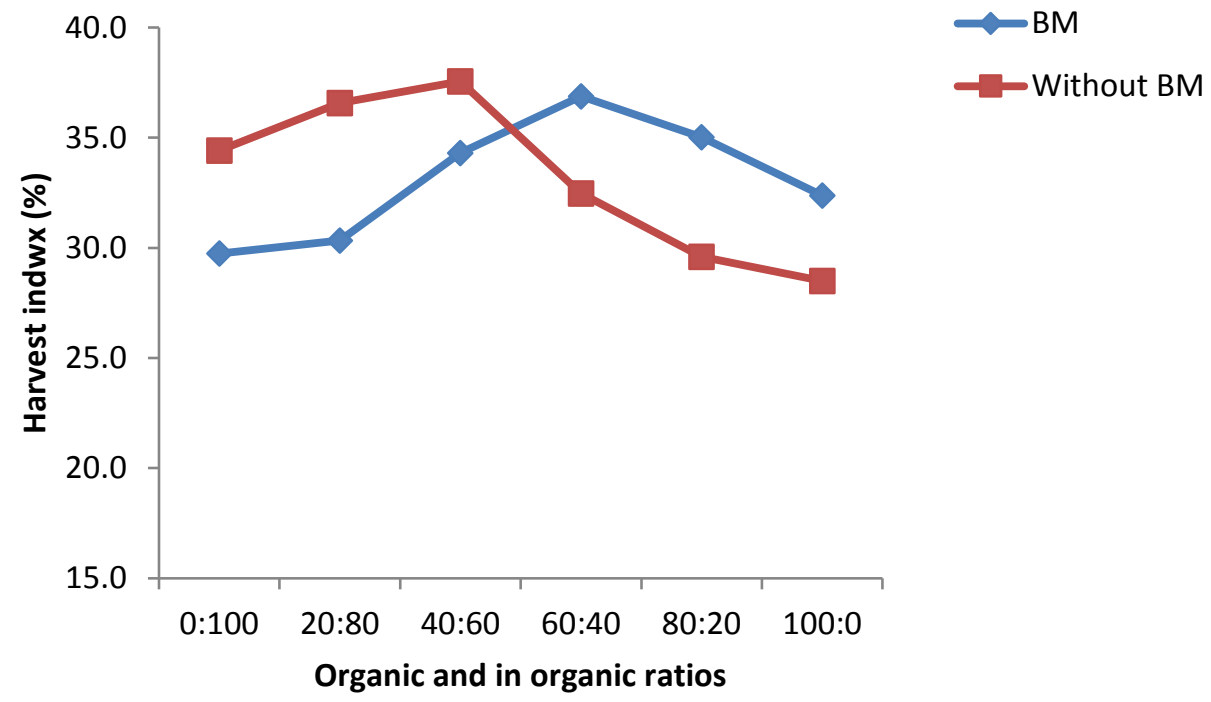

Figure 3. Harvest index as affected by bioaab with organic and inorganic ratios interaction. 
Table 4. Plant height, spike length, grain spike ${ }^{-1}$ and thousand grains weight of wheat as affected by integrated nitrogen management with bioaab

\begin{tabular}{|c|c|c|c|c|}
\hline Treatments & $\begin{array}{l}\text { Plant height } \\
\text { (cm) }\end{array}$ & $\begin{array}{c}\text { Spike length } \\
\text { (cm) }\end{array}$ & Grains spike $^{-1}$ & $\begin{array}{c}\text { Thousand grain } \\
\text { Weight (g) }\end{array}$ \\
\hline \multicolumn{5}{|l|}{$\mathrm{BM}$} \\
\hline With BM & $92.1 \mathrm{a}$ & $10.0 \mathrm{a}$ & $52.0 \mathrm{a}$ & $46.1 \mathrm{a}$ \\
\hline Without BM & $88.2 \mathrm{~b}$ & $9.7 \mathrm{~b}$ & $47.2 \mathrm{~b}$ & $43.4 \mathrm{~b}$ \\
\hline prob. & 0.021 & 0.000 & 0.000 & 0.018 \\
\hline \multicolumn{5}{|l|}{ Ratios } \\
\hline $0: 100$ & $87.2 \mathrm{c}$ & $9.4 \mathrm{~d}$ & $40.8 \mathrm{f}$ & $42.4 \mathrm{~d}$ \\
\hline $20: 80$ & $89.8 \mathrm{bc}$ & $9.7 \mathrm{c}$ & $51.0 \mathrm{c}$ & $45.1 \mathrm{bc}$ \\
\hline $40: 60$ & $92.1 \mathrm{~b}$ & $10.2 \mathrm{~b}$ & $56.7 \mathrm{~b}$ & $46.4 \mathrm{~b}$ \\
\hline $60: 40$ & $97.9 \mathrm{a}$ & $10.6 \mathrm{a}$ & $59.3 \mathrm{a}$ & $48.3 \mathrm{a}$ \\
\hline $80: 20$ & $87.6 \mathrm{c}$ & $9.8 \mathrm{c}$ & $46.0 \mathrm{~d}$ & $44.2 \mathrm{c}$ \\
\hline 100:0 & $86.3 \mathrm{c}$ & $9.5 \mathrm{~d}$ & $43.8 \mathrm{e}$ & $42.3 \mathrm{~d}$ \\
\hline $\operatorname{LSD}_{(0.05)}$ & 2.344 & 0.126 & 1.465 & 1.541 \\
\hline \multicolumn{5}{|c|}{ Planned mean comparison } \\
\hline Control & $73.5 *$ & $8.2 *$ & $38.0 *$ & $40.4 *$ \\
\hline fertilized plots & 90.1 & 9.9 & 49.6 & 44.8 \\
\hline prob. & 0.000 & 0.000 & 0.000 & 0.031 \\
\hline \multicolumn{2}{|c|}{ Interaction } & & & \\
\hline $\mathrm{BM} \times \mathrm{R}$ & NS & 0.005 & 0.048 & NS \\
\hline
\end{tabular}

*Mean with different letter(s) in columns is significantly different at $\mathrm{p} \leq 0.05$

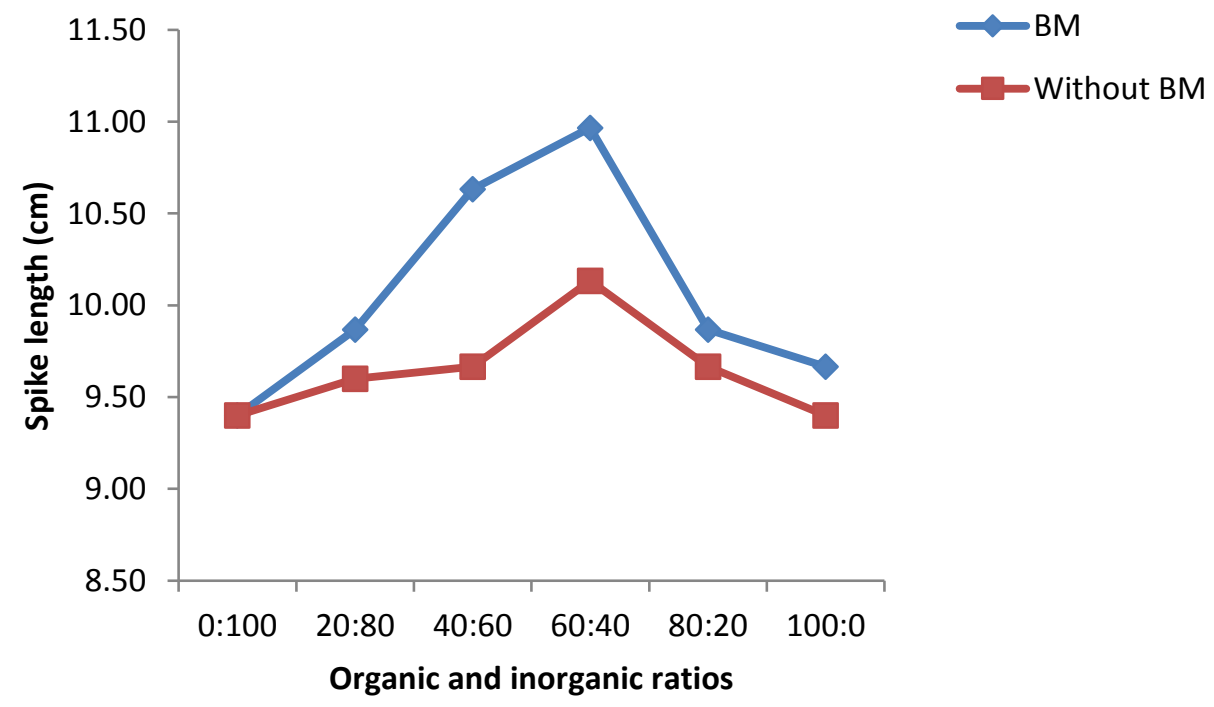

Figure 4. Spike length as affected by bioaab with organic and inorganic ratios interaction 


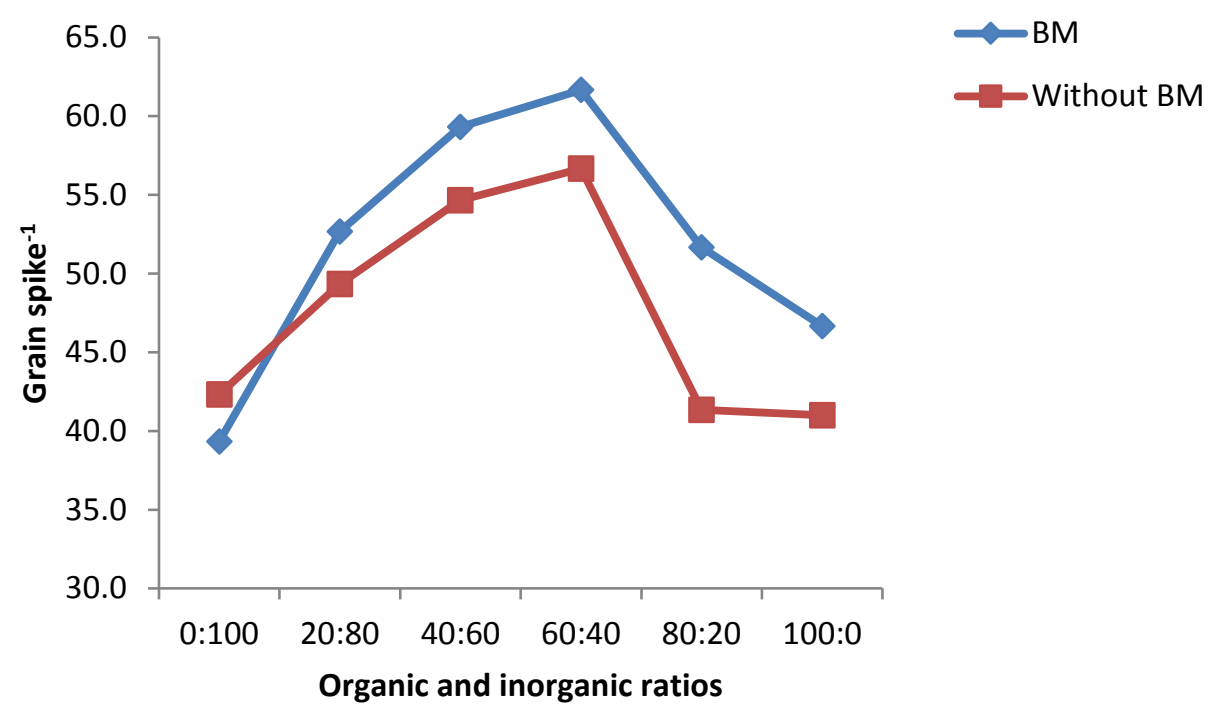

Figure 5. Grain per spike as affected by bioaab with organic and inorganic ratios interaction

Table 5. Effected of integrated nitrogen management with bioaab on post-harvest soil pH, EC(e), lime and soil organic matter

\begin{tabular}{|c|c|c|c|}
\hline Treatments & $\begin{array}{c}\text { pH } \\
(1: 5)\end{array}$ & $\begin{array}{c}\mathrm{EC}(\mathrm{e}) \\
\left(\mathrm{dSm}^{-1}\right)\end{array}$ & $\begin{array}{c}\text { SOM } \\
(\%)\end{array}$ \\
\hline \multicolumn{4}{|l|}{$\mathrm{BM}$} \\
\hline With BM & $7.8 \mathrm{~b}$ & 0.266 & $1.27 \mathrm{a}$ \\
\hline Without BM & $7.9 \mathrm{a}$ & 0.266 & $1.07 \mathrm{~b}$ \\
\hline prob. & 0.000 & 0.001 & 0.03 \\
\hline \multicolumn{4}{|l|}{ Ratios } \\
\hline $0: 100$ & $7.888 \mathrm{a}$ & $0.230 \mathrm{~d}$ & $0.84 \mathrm{~d}$ \\
\hline $20: 80$ & $7.875 b$ & $0.247 \mathrm{c}$ & $1.12 \mathrm{c}$ \\
\hline 40:60 & $7.852 \mathrm{c}$ & $0.260 \mathrm{bc}$ & $1.06 \mathrm{c}$ \\
\hline 60:40 & $7.855 \mathrm{c}$ & $0.273 \mathrm{~b}$ & $1.22 \mathrm{bc}$ \\
\hline $80: 20$ & $7.832 \mathrm{~d}$ & $0.287 \mathrm{ab}$ & $1.33 \mathrm{~b}$ \\
\hline 100:0 & $7.810 \mathrm{e}$ & $0.299 \mathrm{a}$ & $1.45 \mathrm{a}$ \\
\hline $\operatorname{LSD}(0.05)$ & 0.008 & 0.015 & 0.12 \\
\hline \multicolumn{4}{|c|}{ Planned mean comparison } \\
\hline Control & $7.89 *$ & $0.213 *$ & $0.83 *$ \\
\hline fertilized plots & 7.85 & 0.266 & 1.17 \\
\hline prob. & 0.002 & 0.010 & 0.03 \\
\hline \multicolumn{2}{|c|}{ Interaction } & & \\
\hline $\mathrm{BM} \times \mathrm{R}$ & 0.005 & 0.989 & 0.02 \\
\hline
\end{tabular}

*Mean with different letter(s) in columns is significantly different at $\mathrm{p} \leq 0.05$ 


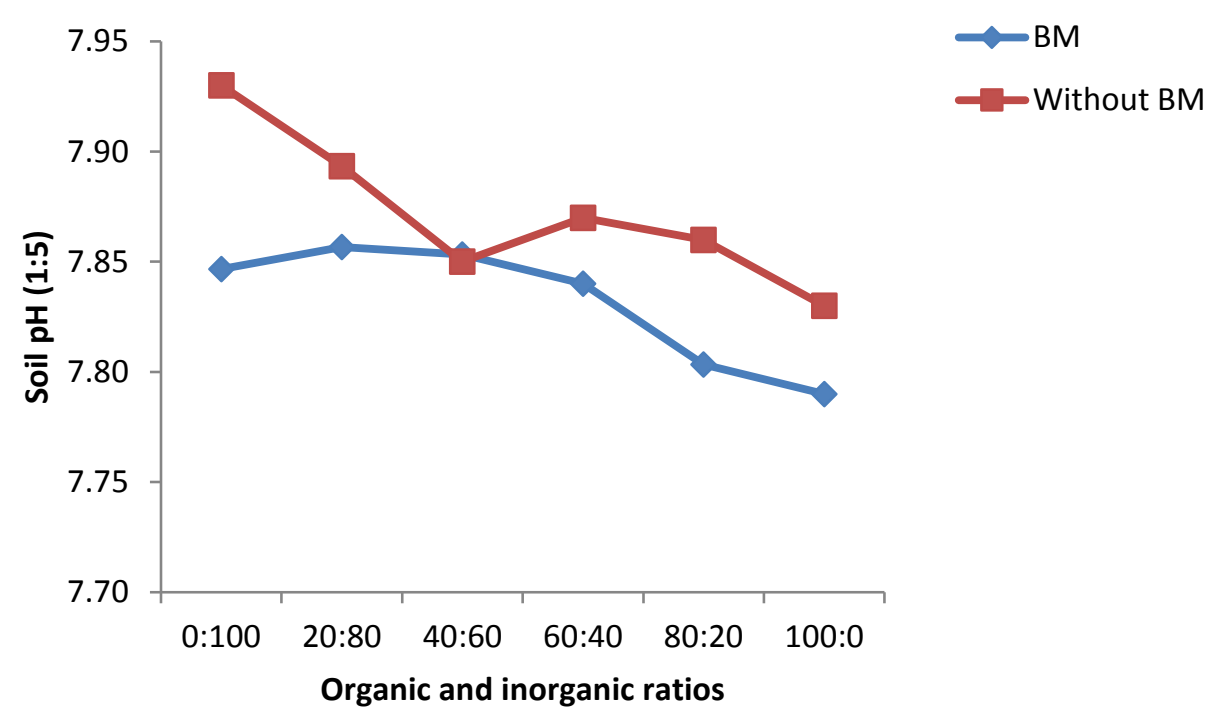

Figure 6. Soil pH as affected by bioaab with organic and inorganic ratios interaction

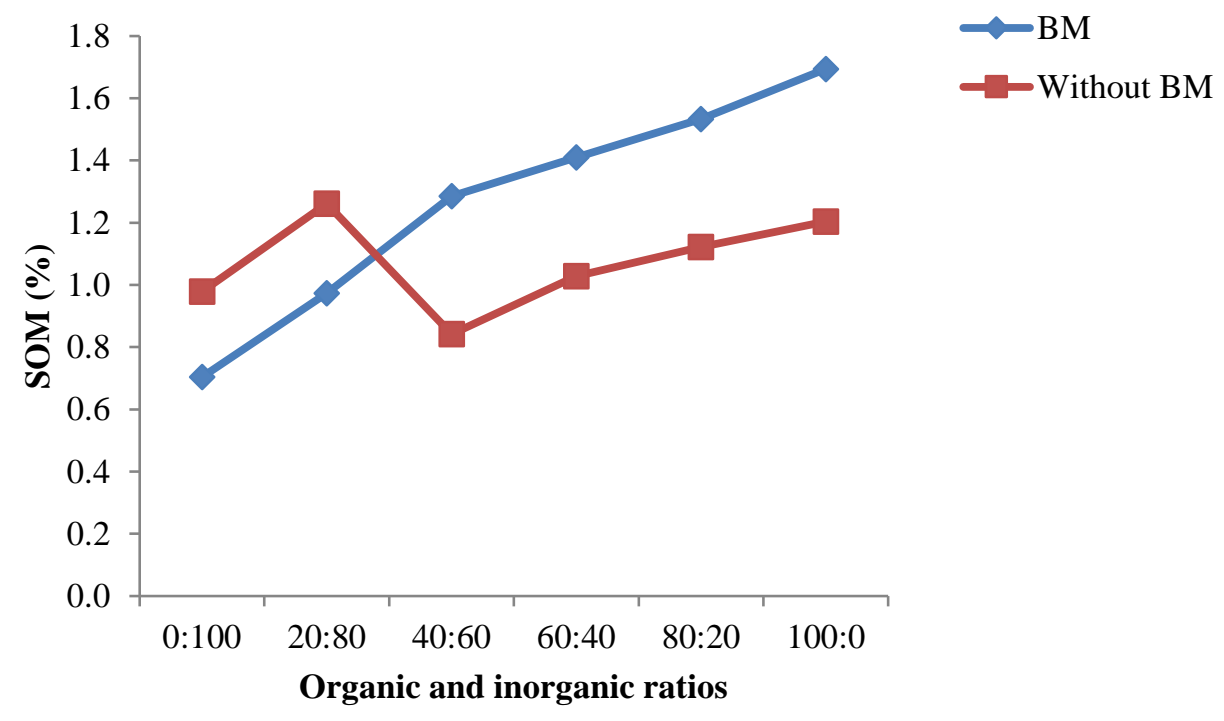

Figure 7. Soil organic matter as affected by bioaab with organic and inorganic ratios interaction 
Table 6. Soil total nitrogen, plant nitrogen concentration and nitrogen uptake of wheat as influenced of integrated nitrogen management with bioaab

\begin{tabular}{|c|c|c|c|}
\hline Treatments & $\begin{array}{c}\begin{array}{c}\text { Soil total Nitrogen } \\
\left(\mathrm{mg} \mathrm{kg}^{-1}\right)\end{array} \\
\end{array}$ & $\begin{array}{c}\text { Plant N } \\
\text { Concentration }(\%) \\
\end{array}$ & $\begin{array}{l}\text { Nitrogen plant } \\
\text { uptake }\left(\mathrm{kg} \mathrm{ha}^{-1}\right) \\
\end{array}$ \\
\hline \multicolumn{4}{|l|}{$\mathrm{BM}$} \\
\hline With BM & $2669.0 \mathrm{a}$ & $1.6 \mathrm{a}$ & $143.5 \mathrm{a}$ \\
\hline Without BM & $2068.8 \mathrm{~b}$ & $1.4 \mathrm{~b}$ & $117.0 \mathrm{~b}$ \\
\hline prob. & 0.000 & 0.043 & 0.003 \\
\hline \multicolumn{4}{|l|}{ Ratios } \\
\hline $0: 100$ & $2012.7 \mathrm{~d}$ & $1.13 \mathrm{e}$ & $89.52 \mathrm{e}$ \\
\hline $20: 80$ & $2165.0 \mathrm{~cd}$ & $1.39 \mathrm{~cd}$ & $120.92 \mathrm{~d}$ \\
\hline 40:60 & $2225.0 \mathrm{c}$ & $1.64 \mathrm{~b}$ & $150.02 \mathrm{~b}$ \\
\hline $60: 40$ & $2791.7 \mathrm{a}$ & $1.78 \mathrm{a}$ & $174.86 \mathrm{a}$ \\
\hline $80: 20$ & $2465.6 \mathrm{~b}$ & $1.50 \mathrm{c}$ & $135.00 \mathrm{c}$ \\
\hline 100:0 & $2553.1 \mathrm{~b}$ & $1.35 \mathrm{~d}$ & $111.04 \mathrm{~d}$ \\
\hline $\operatorname{LSD}_{(0.05)}$ & 174.723 & 0.131 & 11.814 \\
\hline \multicolumn{4}{|c|}{ Planned mean comparison } \\
\hline Control & $1593.333 *$ & $0.92 *$ & $66.56 *$ \\
\hline fertilized plots & 2368.854 & 1.47 & 130.23 \\
\hline prob. & 0.001 & 0.003 & 0.000 \\
\hline \multicolumn{2}{|c|}{ Interaction } & & \\
\hline $\mathrm{BM} \times \mathrm{R}$ & NS & 0.041 & 0.002 \\
\hline
\end{tabular}

*Mean with different letter(s) in columns is significantly different at $\mathrm{p} \leq 0.05$

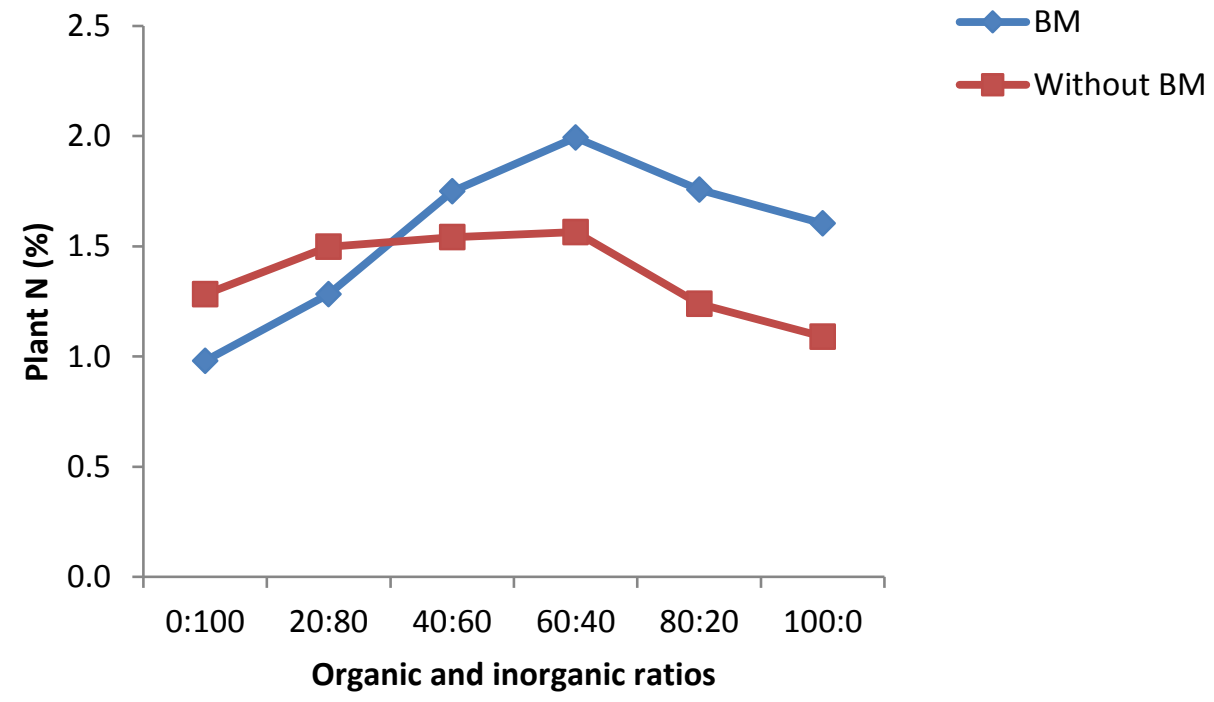

Figure 8. $\mathrm{N}$ in plant as affected by bioaab with organic and inorganic ratios interaction 


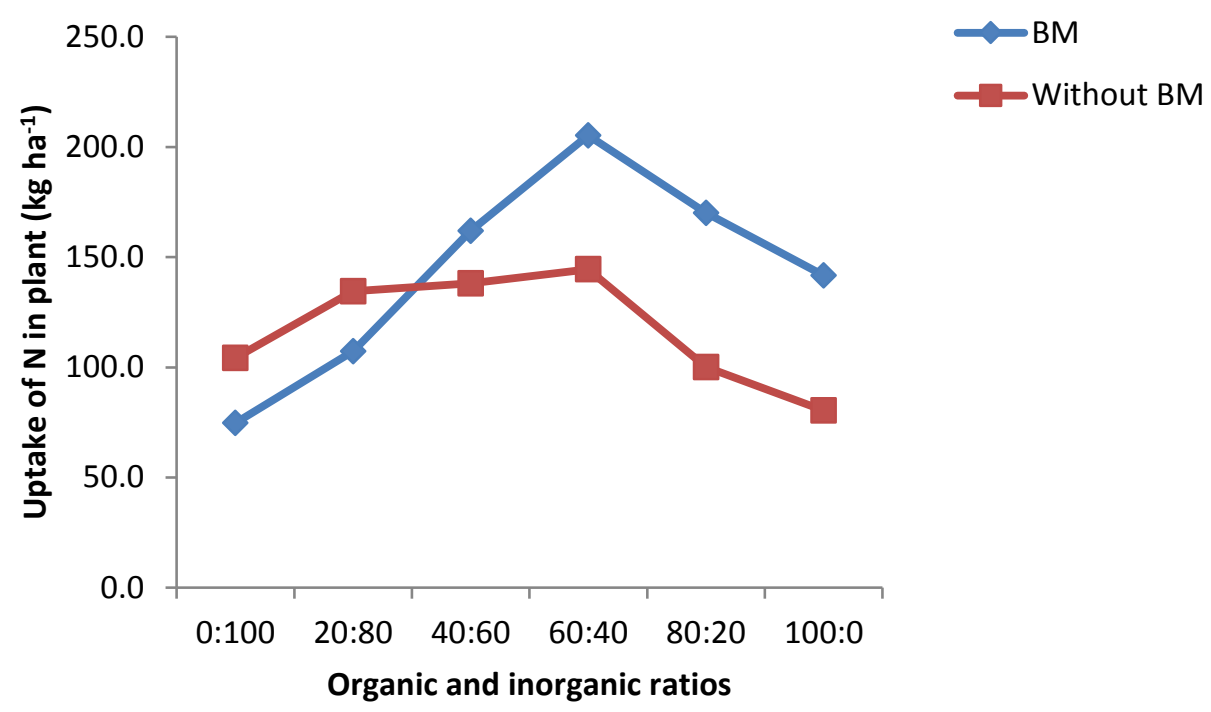

Figure 9. Uptake of $\mathbf{N}$ in Plant as affected by bioaab with organic and inorganic ratios interaction

\section{Conclusion}

Organic and inorganic sources of nitrogen with Bioaab at 60:40 improved yield, nitrogen uptake capability, post-harvest soil total $\mathrm{N}$ and growth parameters of wheat crop. Nitrogen at very low concentration cause poor growth but high dose leads to crop burn and in other cases cause rapid growth with delicate weak stem, which could easily be damaged by environmental shocks such as speedy winds, storms etc. Thus optimum level of nitrogenous fertilizer in order to get high yield with quality of organic crop is a major concern. We suggest that optimum nitrogen fertilizer application and uptake capability of plant is important for increased yield, growth, development and income for growers. Further studies needs to address the different environmental safe organic fertilizers on wheat crop.

\section{Authors' contributions}

Conceived and designed the experiments: I Azeem, K Shah, AA Khan \& H Bibi, Performed the experiments: I Azeem, AA Khan, K Shah, Ibadullah, K Khan \& SAA Shah, Analyzed the data: I Azeem, AA Khan
\& K Shah, Contributed reagents/ materials/ analysis tools: H Bibi, K Azeem \& F Naz, Wrote the paper: I Azeem, AA Khan \& K Shah.

\section{Acknowledgment}

We would like to thank Tasneem Akhtar (School of Life Sciences, USTC) for her critical reading of the manuscript and valuable suggestions.

\section{References}

1. Food UN (2011). Agriculture Organization (FAO), 2011. The state Food and Agriculture.

2. MINFAL (2011). Agriculture statistics of Pakistan. Govt. of Pakistan, Ministry of Food, Agriculture and Livestock, Economic Wing, Islamabad.

3. Malhi SS, Lemke R, Wang ZH \& Chhabra BS (2006). Tillage, nitrogen and crop residue effects on crop yield, nutrient uptake, soil quality, and greenhouse gas emissions. Soil and Tillage Res 90(1-2): 171-183.

4. Gross J (2012). Pigments in Vegetables: Chlorophylls and Carotenoids. Springer, New York, USA. 
5. Shaaban SM (2006). Effect of organic and inorganic nitrogen fertilizer on wheat plant under water regime. Journal of Appl Sci Res 2(10): 650-656.

6. Bodruzzaman M, Meisner CA, Sadat MA \& Hossain MI (2010). Long-term effects of applied organic manures and inorganic fertilizers on yield and soil fertility in a wheat-rice cropping pattern. In Proceedings of the 19th World Congress of Soil Sci, Brisbane, Australia, pp 142-145.

7. Torbert HA, Potter KN \& Morrison JE (2001). Tillage system, fertilizer nitrogen rate, and timing effect on corn yields in the Texas Blackland Prairie. Agronomy J 93(5): 1119-1124.

8. Rasool R, Kukal SS \& Hira GS (2007). Soil physical fertility and crop performance as affected by long term application of FYM and inorganic fertilizers in rice-wheat system. Soil and Tillage Res 96(1-2): 64-72.

9. Higa T (1994). Effective Microorganisms: A new dimension for nature farming. In Proceedings of the Second International Conference on Kyusei Nature Farming. US Department of Agriculture, Washington, DC, USA, pp 20-22).

10. Higa T (2000). What is EM technology? EM World Journal 1:1-6.

11. Hussain T, Anjum AD \& Tahir J (2002). Technology of beneficial microorganisms. Nat Farm Environ 3: 1-14.

12. Hussain T, Javaid T, Parr JF, Jilani G \& Haq MA (1999). Rice and wheat production in Pakistan with effective microorganisms. American $J$ of Alternative Agric 14(1): 30-36.

13. Kim MK, Choi KM, Yin CR, Lee KY, Im WT, Lim JH \& Lee ST (2004). Odorous swine wastewater treatment by purple non-sulfur bacteria, Rhodopseudomonas palustris, isolated from eutrophicated ponds. Biotechnol Letters 26(10): 819822.

14. Shah K, Amin N, Ahmad I, Shah S \& Hussain K (2017). Dust particles induce stress, reduce various photosynthetic pigments and their derivatives in Ficus benjamina: a landscape plant. Inter J Agric Biol 19: 1469-1474.

15. Shah K, ul Amin N, Ahmad I \& Ara G (2018). Impact assessment of leaf pigments in selected landscape plants exposed to roadside dust. Environ Sci and Pollution Res 25(23): 23055-23073.

16. McLean EO (1982). Soil $\mathrm{pH}$ and lime requirement. Methods of soil analysis. Part 2. Chemical and Microbiological properties, (methodsofsoilan2), 199-224.

17. Rhoades JD \& Miyamoto S (1990). Testing soils for salinity and sodicity. Testing Soils for Salinity and Sodicity 299-336.

18. Black CA (1965). Methods of soil analysis, part II. Amer Soc Inc Pub, Madison, USA 770-79.

19. Javaid A, Bajwa R \& Anjum T (2008). Effect of heat-sterilization and EM (effective microorganisms) application on wheat (Triticum aestivum L.) grown in organic-amended sandy loam soil. Cereal Res Communi 36(3): 489-499.

20. Sharif M, Khan M, Khan MA, Wahid F, Marwat KB, Khattak AM \& Naseer M (2015). Effect of rock phosphate and farmyard manure applied with effective microorganisms on the yield and nutrient uptake of wheat and sunflower crops. Pak $J$ of Bot 47: 219-226.

21. Shah SA, Shah SM, Wisal M, Shafi M, Haq N, Samreen S \& Amir M (2010). Effect of integrated use of organic and inorganic nitrogen sources on wheat yield. Sarhad J of Agric 26(4): 559-563.

22. Muhammad H, Khan AZ \& Shah Z (2012). The impact of beneficial microbes (BM) on enhancing efficiency of organic and inorganic $\mathrm{N}$ fertilizers sources. $\mathrm{PhD}$. Thesis. Deptt. Agron. Uni. Agri. Pesh.

23. Muhammad H, Zaman A, Khalil SK \& Shah Z (2014). Effect of beneficial microbes $(\mathrm{BM})$ on the efficiency of organic and inorganic $\mathrm{N}$ fertilizers on wheat crop. Sarhad J of Agric 30(1).

24. Neila A, Adnane B, Manel B, Boulbaba L, Cherki G \& Bouaziz S (2012). Symbiotic 
responses to insoluble phosphorus supply in common bean (Phaseolus vulgaris L.): Rhizobia symbiosis. African $J$ of Biotechnol 11(19): 4360-4367.

25. Sadur R, Khalil SK, Fida M, Abdur R, Khan AZ, Saljoki AR \& Khalil IH (2010). Phenology, leaf area index and grain yield of rainfed wheat influenced by organic and inorganic fertilizer. Pak $J$ of Bot 42(5): 3671-3685.

26. Arif M, Ali S, Khan A, Jan T \& Akbar M (2006). Influence of farm yard manure application on various wheat cultivars. Sarhad J of Agric 22(1): 27.

27. Malhi SS, Lemke R, Wang ZH \& Chhabra BS (2006). Tillage, nitrogen and crop residue effects on crop yield, nutrient uptake, soil quality, and greenhouse gas emissions. Soil and Tillage Res 90(1-2): 171-183.

28. Khan AA, Bibi H, Ali Z, Sharif M, Shah SA, Ibadullah H, Khan K, Azeem I, Ali S (2017). Effect of compost and inorganic fertilizers on yield and quality of tomato. Acad J Agric Res 5(10): 287-293.

29. Aggarwal V \& Nayyar VK (1998). Available soil sulphur status and sulphur nutrition of wheat crop. Journal of the Indian Soc of Soil Sci 46(1): 71-75.

30. Brady NC \& Weil RR (1999). The nature and properties of soil 12th ed. Mac Pub Com New York, pp 625-640.

31. Sarwar G, Schmeisky H, Hussain N, Muhammad S, Ibrahim M \& Safdar E (2008). Improvement of soil physical and chemical properties with compost application in rice-wheat cropping system. Pak J of Bot 40(1): 275-282.

32. Kumar K \& Goh KM (2002). Management practices of antecedent leguminous and non-leguminous crop residues in relation to winter wheat yields, nitrogen uptake, soil nitrogen mineralization and simple nitrogen balance. European $J$ of Agronomy 16(4): 295-308.

33. Kravchenko AG \& Thelen KD (2007). Effect of winter wheat crop residue on notill corn growth and development. Agronomy J 99(2): 549-555.

34. Agbede TM, Oladitan TO, Alagha SA, Ojomo AO \& Ale MO (2010). Comparative evaluation of poultry manure and NPK fertilizer on soil physical and chemical properties, leaf nutrient concentrations, growth and yield of yam (Dioscorea rotundata Poir) in southwestern Nigeria. World $J$ of Agric Sci 6(5): 540-546.

35. Cocking EC (2003). Endophytic colonization of plant roots by nitrogenfixing bacteria. Plant and soil 252(1): 169-175.

36. Khaliq A, Abbasi MK \& Hussain $T$ (2006). Effects of integrated use of organic and inorganic nutrient sources with effective microorganisms (EM) on seed cotton yield in Pakistan. Bioresource Technol 97(8): 967-972.

37. Kuzyakov Y (2002). Factors affecting rhizosphere priming effects. $J$ of Plant Nutrition and Soil Sci 165(4): 382-396.

38. Rautaray SK, Ghosh BC \& Mittra BN (2003). Effect of fly ash, organic wastes and chemical fertilizers on yield, nutrient uptake, heavy metal content and residual fertility in a rice-mustard cropping sequence under acid lateritic soils. Bioresource Technol 90(3): 275-283.

39. Shah Z \& Ahmad MI (2006). Effect of integrated use of farm yard manure and urea on yield and nitrogen uptake of wheat. J of Agric and Biological Sci 1(1): 60-65. 